Faculty of Science

Faculty Publications

Energy balance microclimatic variations on a coastal beach

Stanton E. Tuller

1972

(C) 1972 Stanton E. Tuller. This article is an open access article distributed under the terms and conditions of the Creative Commons Attribution (CC BY) license.

http://creativecommons. org/licenses/by/4.0/

This article was originally published at:

https://doi.org/10.3402/tellusa.v24i3.10639

Citation for this paper:

Tuller, S. E. (1972). Energy balance microclimatic variations on a coastal beach.

Tellus, 24(3), 260-270. https://doi.org/10.3402/tellusa.v24i3.10639 


\section{Tellus}

\section{Energy balance microclimatic variations on a coastal beach}

\section{Stanton E. Tuller}

To cite this article: Stanton E. Tuller (1972) Energy balance microclimatic variations on a coastal beach, Tellus, 24:3, 260-270, DOI: 10.3402/tellusa.v24i3.10639

To link to this article: https://doi.org/10.3402/tellusa.v24i3.10639
(c) 1972 The Author(s). Published by Taylor and Francis Group LLC

曲 Published online: 15 Dec 2016.

Submit your article to this journal $\widetilde{ }$

Џ Article views: 170

Q View related articles $\asymp$ 


\title{
Energy balance microclimatic variations on a coastal beach
}

\author{
By STANTON E. TULLER University of Victoria, Victoria, British Columbia, Canada
}

(Manuscript received December 12, 1971; revised version February 18, 1972)

\begin{abstract}
This report investigates the variation in energy balance microclimate that occurs across a coastal beach on a clear day. Four beach zones differing only in moisture conditions were selected for comparison. The completely dry sand with its high albedo and hot daytime surface temperatures had the lowest daily net radiation total. Over $90 \%$ of this was transferred to the air by sensible heat flux. The saturated sand surface of the swash zone and the water surface of the surf zone had more of a marine climate. The great bulk of the high daily net radiation went into ground storage with most of the rest being used for evaporation. The wet sand zone represented the true transition zone of the beach and displayed a microclimate intermediate between the extremes of dry sand and ocean. Most of the net radiation went for evaporation, whose total was greater than that of the completely moist zones because of higher vapor pressure gradients. A marked difference in microclimate, caused by differing surface moisture. conditions is seen to exist in a very small horizontal distance under conditions of clear skies. Day and night patterns are reversed with differences between zones much more extreme under the influence of the daytime input of solar radiation.
\end{abstract}

\section{Introduction}

Climatologists have long realized that the major factor controlling the microclimate within a single region is the nature of the surface. The modern viewpoint in climatology emphasizes that it is the role of the surface in governing the exchanges of heat and moisture between the earth's surface and the atmosphere (often called the energy balance) that controls the local microclimate.

One of the most important characteristics of the surface is its moisture state. Many studies have dealt with the difference between marine and continental climates. Little work has been done, however, to examine the energy balance climatic transition in the zone between the ocean and dry land, the shoreline (examples include: Poltaraus, 1962; Kazhdan et al., 1964, and Sakali \& Zorina, 1961). Shorelines, because of their rapid change in surface moisture conditions, exhibit a sharp microclimatic gradient. In order to gain some idea of the nature and magnitude of this gradient a program of field observation was undertaken on a coastal beach in Southern California, USA, during the spring and summer of 1969 . This paper describes the results obtained during one day of that study, a clear day of very complete measurements when climatic differences across the beach are especially well defined. Emphasis is on the energy balance. The longer term variations and the influence of other weather types will be the subject of a future report.

\section{Methodology}

The study site was a sandy beach (Topanga Beach), located five miles west of Santa Monica, California (Fig. 1). The coordinates were $34^{\circ} 2 .^{\prime} 5 \mathrm{~N}$ latitude; $118^{\circ} 35 .^{\prime} 6 \mathrm{~W}$ longitude. The trend of the beach was east-west, giving it a southerly exposure. This orientation was preferred because it provided a symmetrical daily distribution of incident solar radiation around solar noon, and oriented the shoreline parallel to the prevailing land-sea breezes in the region. A bare sand beach was selected which was essentially homogeneous except for the moisture content of the sand. It was this variable that was responsible for the microclimatic variation across the beach.

Four beach zones were selected for comparison based on soil moisture content. The "dry 


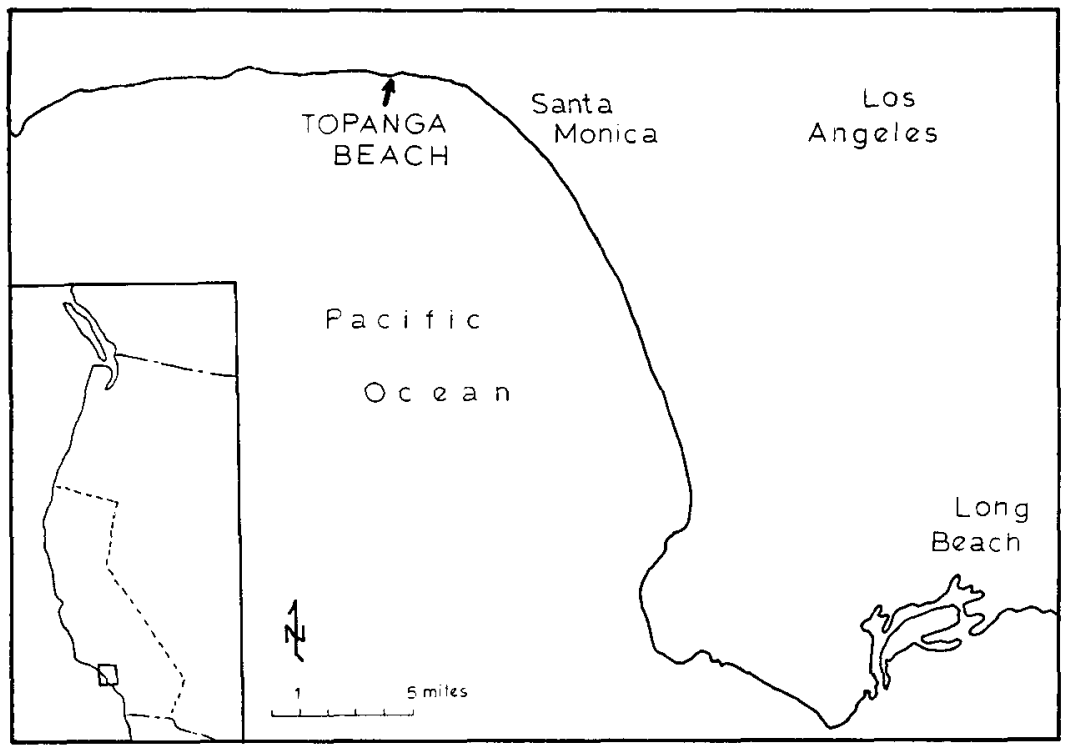

Fig. 1. Location map.

sand" zone was completely dry. The "wet sand" zone had been moistened by a previous high tide but was above the tide line at the time of observation. The average moisture content was $7 \%$ by weight. The "swash" zone was completely saturated by the uprush of a recent wave. The surface was not covered by surf at the moment of observation and was directly exposed to the atmosphere. Moisture content was $20 \%$ by weight. As a final point of comparison measurements were taken over the "surf" zone, composed of wave roughened water approximately 1 meter in depth.

The following climatic parameters, directly measured during the study, will be examined in this report: solar radiation $(Q+q)$, reflected solar radiation $(A)$; net radiation $(R)$; radiant temperature of the surface and sky ( $T_{\mathrm{sfc}}$ and $\left.T_{\text {sky }}\right)$; ground heat flux $(G)$; and dry and wet bulb temperature.

Solar radiation parameters were measured with a Dirmhirn-Sauberer star pyranometer manufactured by Kahl Scientific Instrument Corp. and calibrated by Professor Dirmhirn of Utah State University. A glass dome limited the response of the instrument to wavelengths between 0.3 and 3.0 microns. Output was read directly in $1 y / m i n$ on an associated moving coil meter calibrated with the instrument. A detailed description of the star pyranometer is given by Dirmhirn (1958).
Net radiation $(R)$ was measured with a polyethelene shielded net radiometer manufactured by Kahl Scientific Instrument Corp. and calibrated by Professor Dirmhirn. Response was 0.3 to 60.0 microns. Its readings were checked against those of net radiation derived independently from the components of the shortand longwave radiation balances.

Apparent radiant temperatures ( $T_{\mathrm{sfc}}$ and $T_{\text {sky }}$ ) were measured with a Stoll-Hardy infrared radiometer produced by the Williamson Development Corp. An infrared filter limited response to wavelengths greater than 3.0 microns. The instrument measured the amount of longwave radiation within a $20^{\circ}$ field of view and indicated the radiant temperature $\left({ }^{\circ} \mathrm{C}\right)$. In this study no differentiation was made between the emitted and reflected longwave radiation from a target. 'The term "apparent" radiant temperature is used to indicate the magnitude of longwave flux from a given target and includes both reflected and emitted components. It therefore differs somewhat from the "true" radiant temperature. The total longwave radiation flux coming from the target ( $(1 \mathrm{y} / \mathrm{min})$ was computed from the StefanBolzmann equation. The instrument was calibrated both before and after the study by means of a Leslie cube and no deviation was observed. Radiant sky temperatures were taken by sampling the zenith and the four 
cardinal directions and averaging the results. The surface temperature was observed with a single measurement pointing the sensor vertically downward.

Ground heat flux $(G)$ was measured on the wet and dry sand zones by heat flux transducers manufactured by C. W. Thornthwaite \& Associates. The transducers were buried in the sand at a depth of $1.0 \mathrm{~cm}$ and their output was recorded on a Rustrak voltmeter.

Wet and dry bulb temperatures were measured with an Assman aspiration psychrometer. Heat and water vapor flux were determined over the wet sand by observing the temperature and humidity of the surface and at $80 \mathrm{~cm}$. The surf and swash zones employed an air observation at $80 \mathrm{~cm}$ but utilized the apparent radiant surface temperature to compute the vapor pressure of the saturated surface.

Other components of the energy balance (evaporative $(L E)$, and sensible $(H)$ heat fluxes) were computed via the energy balance technique on the wet and dry sand zones. Evaporative heat flux was negligible on the dry sand zone so sensible heat flux was: $H=$ $R-G$. On the wet sand zone the Bowen ratio $(B)$ was computed via:

$$
B=0.49 \frac{T_{s}-T_{a}}{e_{s}-e_{a}}
$$

where $T$ is the dry bulb temperature $\left({ }^{\circ} \mathrm{C}\right), e$ is the vapor pressure $(\mathrm{mmHg}), 0.49$ is the psychrometric constant, and $s$ and $a$ refer to the surface and air respectively. Evaporative heat flux was then determined by:

$$
L E=\frac{R-G}{1+B}
$$

Sensible heat flux was taken as the residual in the energy balance equation:

$$
H=R-G-L E
$$

Ground heat flux could not be directly measured in the fluid medium of the surf and swash zones. Thus the aerodynamic method was used to compute the components of the energy balance. Evaporation was determined by the use of the Dalton equation:

$$
E=C\left(e_{s s}-e_{a}\right)
$$

where $e_{s s}$ is the vapor pressure of the saturated surface (corrected for salt water) and $C$ is a function of the wind speed. In this study values of $C$ were those published in Geiger (1966, p. 255). In the ranges of wind speed found on the study day $(2.5-3.5 \mathrm{~m} / \mathrm{sec})$ the values of his coefficients determined from atmometer measurements are close to the function Penman (1956) established for open water evaporation. Use of the two coefficients produce a deviation of about $0.0015 \mathrm{~mm} / \mathrm{hr}$ in the evaporation rate and about $0.0015 \mathrm{ly} / \mathrm{min}$ in the computed flux of latent heat. Wind speed was measured with a C. W. Thornthwaite Associates wind profile system. Evaporative heat flux was obtained by multiplying $E$ by the latent heat of vaporization $(L)$.

The Bowen ratio was computed and $H$ was determined via $H=B \cdot L E$. $G$ was taken as the residual in the energy balance equation.

Because of the simplification and assumptions inherent in the methods utilized to compute the energy balance over the ocean and swash zones some degree of caution should be used when interpreting the results. The findings appear to be reasonable, however, and are considered to be close to reality. The results compare favorably with the calculated results presented by Roden (1959) for the energy balance of the adjacent California Current.

In certain situations advection of energy may become an added term in the energy balance equation. In this study, however, advected energy was considered to be inconsequential from both theoretical and practical viewpoints. Advection is the horizontal transport of energy and, as such, must be measured through vertical borders. Its effect is seen as the addition or subtraction of energy in a volume of air. The horizontal earthatmosphere interface, dealt with in this study, has neither volume nor vertical borders. The influence of advection does not apply (see Hofmann, 1966).

Where advection would become influential is by affecting the readings taken at the upper level used to determine the fluxes of sensible heat and moisture. Budyko (1956, pp. 7-8) treated the subject of advection and concluded that even for air layers 10 to $100 \mathrm{~m}$ deep the horizontal flux of energy is so much smaller than the vertical flux that it can be disregarded in most studies. The ratio between horizontal and vertical fluxes becomes less as the surface 


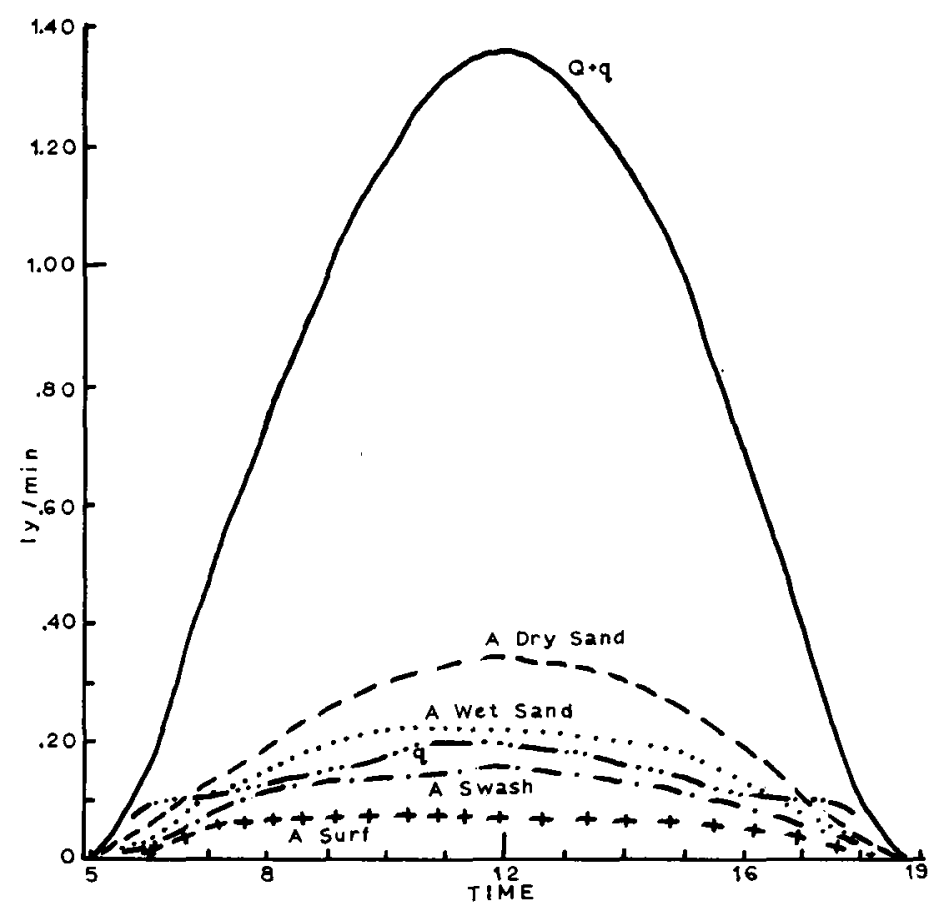

Fig. 2. Graphs of the daily pattern of solar radiation parameters.

is approached. In this study the measurements at the upper level were taken at $80 \mathrm{~cm}$. This was considered to be below the critical height where problems of advection would tend to become critical (for a discussion of this see Sellers, 1965, pp. 124-126 and 146).

A unique feature of the study site helped to further alleviate any problems of advective heat transfer. The land and sea breezes in this area were generated by the Los Angeles basin to the east (see Fig. 1), and flowed parallel to the mountains immediately becking the study area. Thus, they blew parallel to the shoreline and the borders between beach zones.

Substantial advection of energy beneath the sea surface does occur and is very important in determining the energy balance of that surface. In this study of the air-surface interface, however, this advected energy merely helps to supply or remove energy flowing into or out of the surface. Its effect at the interface is measured as part of $G$ and does not in any way change the energy balance equation for this horizontal interface. The important role of $G$ and associated sub-surface advection in the moderation of the surf zone climate will be discussed later.

Observations reported on in this study were taken on the clear day of May 9, 1969. Measurements of each climatic parameter were taken at intervals of 1 hour or less over each zone. The results were than graphed to obtain a daily curve.

\section{Results}

\section{Solar radiation}

Fig. 2 presents the daily pattern of incident direct and diffuse solar radiation and the radiation reflected from the four beach zones. Global solar radiation $(Q+q)$ showed a regular curve with a peak value of $1.36 \mathrm{ly} / \mathrm{min}$ centered on noon.

Diffuse radiation $(q)$ varied between 0.10 $\mathrm{ly} / \mathrm{min}$ in the early morning and late afternoon and $0.20 \mathrm{ly} / \mathrm{min}$ at mid-day. The morning values were higher than those in the afternoon. Concurrently the direct beam radiation was higher in the afternoon. Calculations of the 
atmospheric transmission coefficient showed the afternoon values to be 5-6\% higher than those in the morning. This could be due to greater low level haze under the more stable atmosphere of the morning or to pollutants carried over the study site by the easterly wind (land breeze) from the Los Angeles basin. The afternoon wind was from the west and would presumably be cleaner having originated over the ocean.

Daily totals of solar radiation were: diffuse, $100 \mathrm{ly}$; direct, $541 \mathrm{ly}$; global, $641 \mathrm{ly}$; and solar radiation at the top of the atmosphere, $981 \mathrm{ly}$.

Reflected solar radiation differed greatly between beach zones. At mid-day the reflection was: dry sand, $0.34 \mathrm{ly} / \mathrm{min}$; wet sand, 0.22 $\mathrm{ly} / \mathrm{min}$; swash, $0.16 \mathrm{ly} / \mathrm{min}$, and surf, $0.08 \mathrm{ly} /$ min. Thus the wet sand reflection was $65 \%$, the swash zone $47 \%$, and the surf zone $23 \%$, of the dry sand value respectively.

Measurement of reflection over still water, a pond on the beach nearby, showed values about $0.01 \mathrm{ly} / \mathrm{min}$ less than those over the wave roughened surf near mid-day. The effect of waves on reflection was thus small but measurable. This substantiates the theoretical results presented by others (Burt, 1954; TerMarkariants, 1957; see also Kondratyev, 1969, pp. 431-434) that wave-roughened surfaces
Table 1. Albedo (\%)

$\begin{array}{lrrrrrrrrrrr}\text { Time } & 07 & 08 & 09 & 10 & 11 & 12 & 13 & 14 & 15 & 16 & 17 \\ \text { Solar altitude } & & & & & & & & & & & \\ \quad \text { (deg.) } & 24 & 36 & 49 & 61 & 72 & 76 & 70 & 59 & 45 & 34 & 20 \\ \text { Dry sand } & 30 & 27 & 26 & 26 & 25 & 25 & 26 & 26 & 26 & 27 & 29 \\ \text { Wet sand } & 24 & 20 & 20 & 19 & 17 & 16 & 16 & 17 & 18 & 19 & 21 \\ \text { Swash zone } & 17 & 16 & 13 & 12 & 12 & 12 & 12 & 12 & 12 & 14 & 16 \\ \text { Surf zone } & 13 & 9 & 6 & 6 & 6 & 6 & 6 & 6 & 7 & 9 & 11\end{array}$

have higher reflection than still water at high solar altitudes. The absolute differences in reflection between zones increased toward mid-day when the inputs of solar energy were large and solar angles high but became small near the end of the day. This same patterns has been reported on a global scale (Sellers, 1965) where the differences in albedo between oceanic and continental areas is quite large at low latitudes (high sun angles) but becomes small at high latitudes.

The mid-day reflection dominated the daily total and differences between zones were appreciable: dry sand, $170 \mathrm{ly}$; wet sand $120 \mathrm{ly}$; swash, $81 \mathrm{ly}$; and surf $45 \mathrm{ly}$. Differences in reflection accounted for $47 \%$ of the differential in daytime net radiation between the dry sand and surf zone and $41 \%$ of the dry sand-wet sand difference.

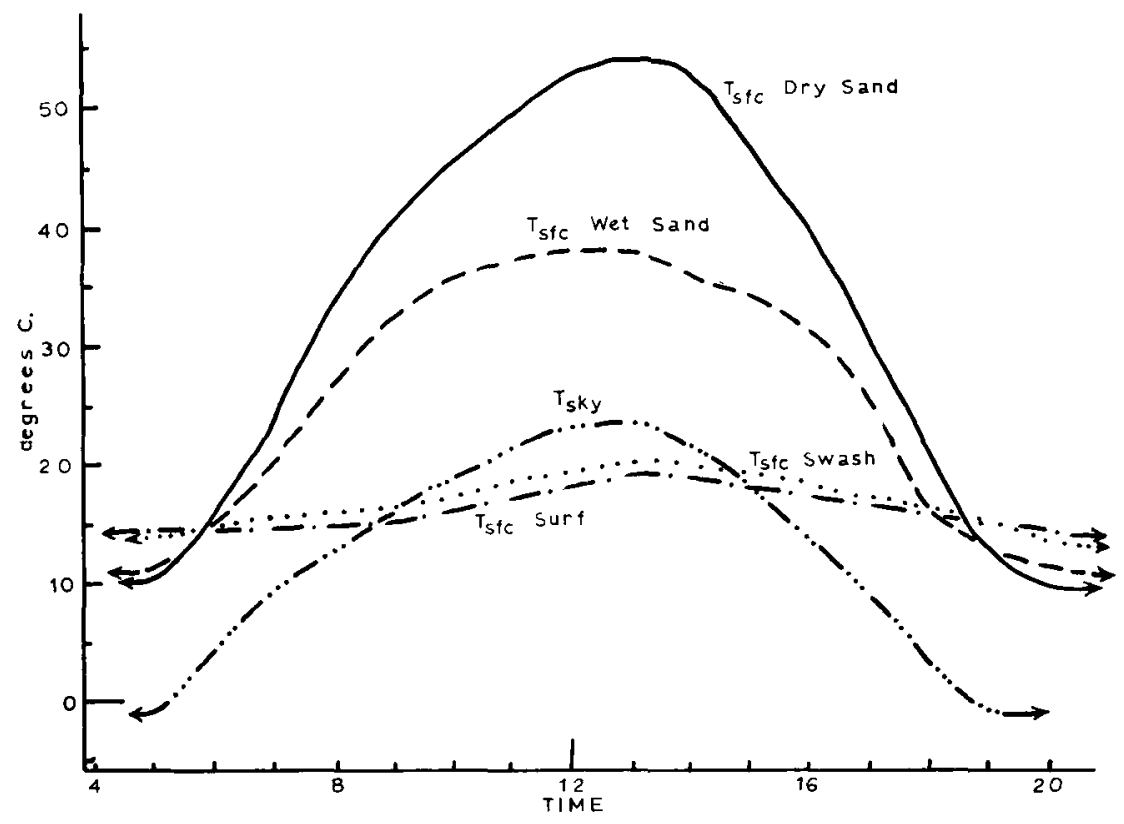

Fig. 3. Apparent radiant temperatures of the surface and sky. 


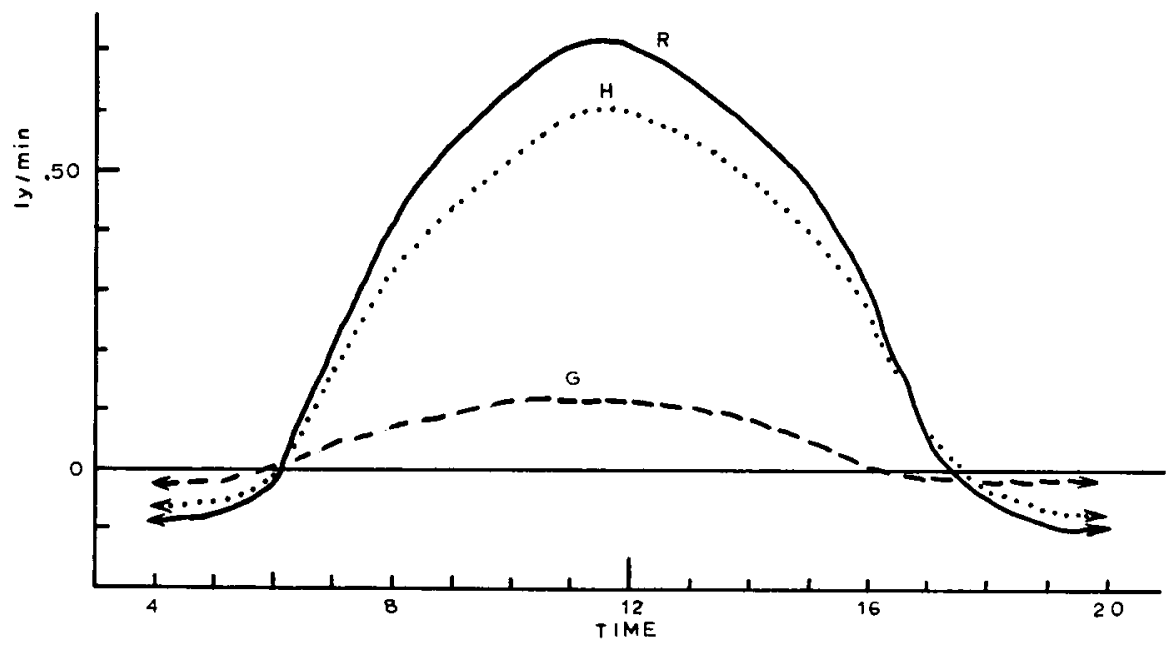

Fig. 4. The energy balance-dry sand zone.

Reflected solar radiation expressed as a percentage of $Q+q$ (albedo) is presented in Table 1. These values fall within the range of albedos for roughly similar surfaces given by other authors (i.e. Sellers, 1965; Kondratyev, 1969). The values are typical of those recorded under other clear conditions during the longer study.

\section{Surface temperature and longwave radiation}

The dry sand with a limited amount of conduction into the surface and no evaporative

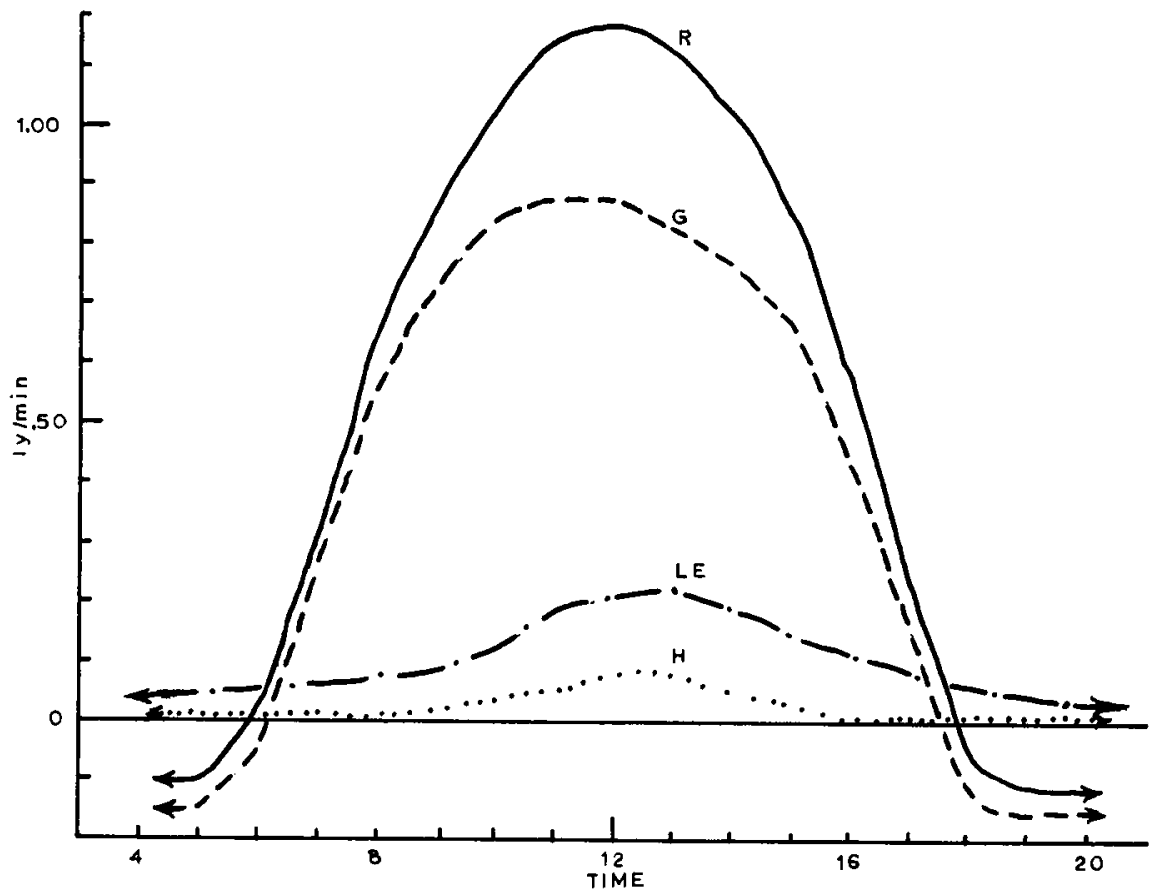

Fig. 5. The energy balance swash zone. 


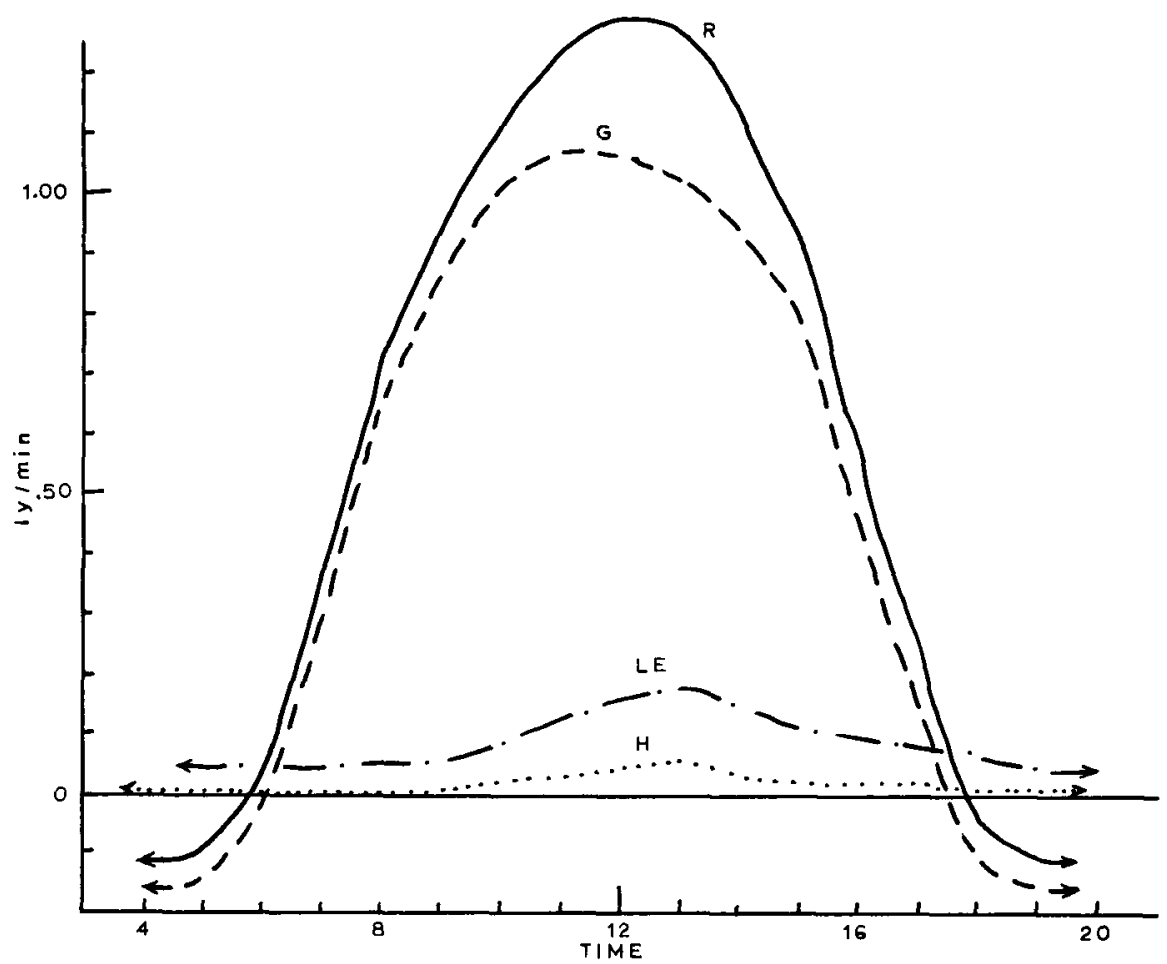

Fig. 6. The energy balance--surf zone.

cooling showed a high daytime surface temperature and a large diurnal range (Fig. 3). The more moist zones showed a progressively lower peak and reduced range. The roles of evaporative cooling and the storage of energy in water are well illustrated by the diurnal temperature patterns.

The dry sand lost a great deal of energy through longwave radiation exchange because of its high daytime surface temperatures. The swash and surf zones, however, were seen to actually gain energy by longwave radiation during the middle of the day when the sky warmed to a higher radiant temperature than the surface. At night the warmer surfaces had greater losses of radiant energy, but the differences between zones were small, only 17 ly between the surface and dry sand during the entire night.

\section{Net radiation and the energy balance}

Figs. 4-7 show the diurnal patterns of the components of the energy balance for the four beach zones. The greater absorption of solar radiation and lower surface temperatures give the moister zones substantially greater totals of net radiation $(R)$ during the daytime. Warmer surface temperatures supported by energy stored during the day produced greater losses of longwave energy at night. The differences between zones were much greater under the maximum inputs of solar energy during the daylight hours, however, and nocturnal gradients were quite small. Table 2 shows the difference in net radiation between the dry sand and surf zones was 272 ly during the day but only 17 ly at night.

The bulk of the net radiation on the dry sand (Fig. 4) was transferred to the atmosphere by sensible heat flux $(H)$. The proportion was $86 \%$ at mid-day and $92 \%$ of the daily total. The pattern of $H$ closely followed $R$ throughout the the day. The peak of ground heat flux $(G)$ was offset toward the morning when the soil was rapidly warming. Both $H$ and $G$ were negative at night.

Ground heat flux dominated the energy balance on both the swash (Fig. 5) and surf (Fig. 6) zones. For the surf zone $G$ made up almost $90 \%$ of $R$ at mid-day and $75 \%$ of the 


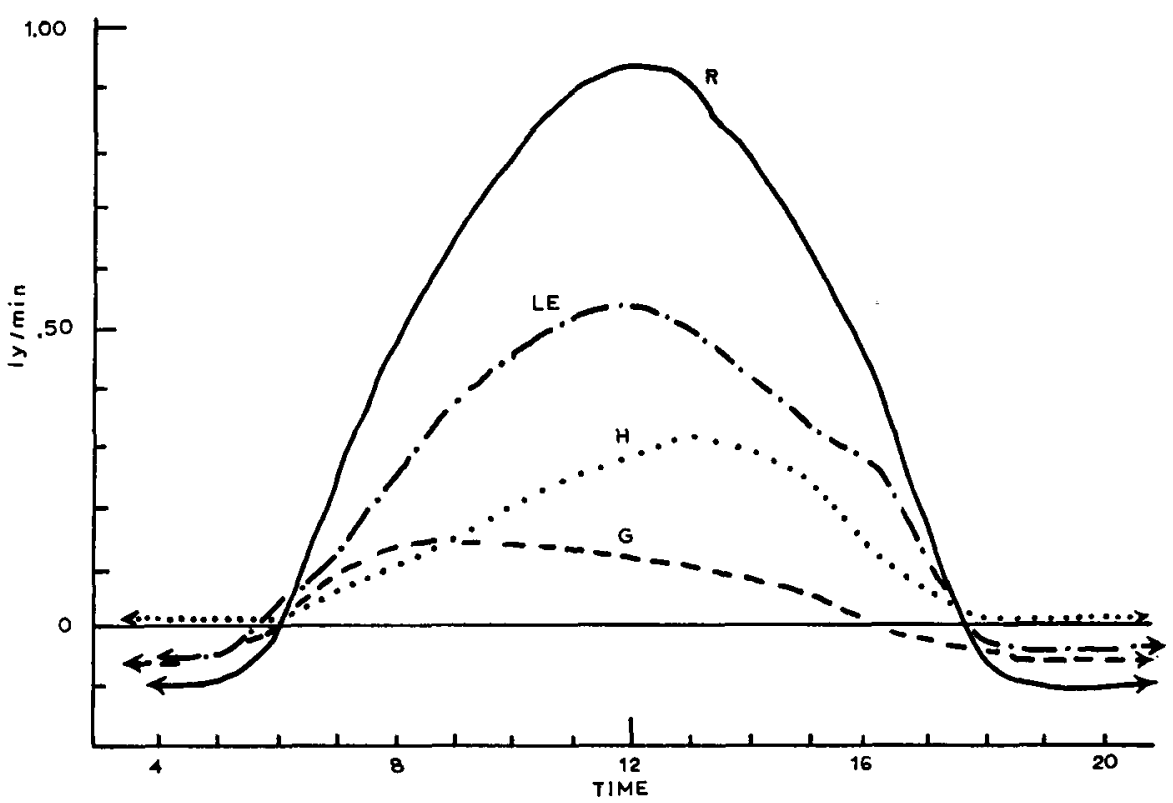

Fig. 7. The energy balance-wet sand zone.

daily total. This demonstrates the great moderating potential of a moving, fluid medium; provided by its ability to store radiant energy. Only $20 \%$ of the daily surf zone net radiation was used to evaporate water and $5 \%$ to directly heat the air. Very similar proportions were found by Roden (1959) in a study of the California Current. His energy balance, calculated for the portion of the current offshore from the study area in the month of May, showed $22 \%$ of the daily $R$ going into $L E, 78 \%$ into $G$ and only $1 \mathrm{ly} /$ day for $H$.

On both the swash and surf zones the peak of $G$ occurred in the morning and the maxima of $L E$ and $H$ were delayed until the afternoon. Energy stored during the day was sufficient to drive positive $L E$ and $H$ at night.

The wet sand (Fig. 7) showed the most even distribution among the components of the energy balance. $L E$ accounted for $55 \%$ of the daily net radiation; $H, 38 \%$; and $G 7 \%$. It is interesting that evaporation was greater over the wet sand than over the swash or surf zones. The noon values of $L E$ were: wet sand, $0.53 \mathrm{ly} / \mathrm{min}$; swash, $0.21 \mathrm{ly} / \mathrm{min}$; and surf, 0.16 $\mathrm{ly} / \mathrm{min}$. The daily totals were $197 \mathrm{ly}, 116 \mathrm{ly}$ and 101 ly respectively. Even though the surface moisture and net radiation were less for the wet sand they were not low enough to have a strongly limiting effect. The higher surface temperature and drier air produced a stronger vapor pressure gradient over the wet sand. This was especially noticeable in the morning but declined with a drying of the sand in the afternoon. In this case the enabling condition, the vapor pressure gradient, outweighed the influence of available energy and a more limited moisture supply.

About $15 \%$ of the daytime net radiation went into $G$ but over $60 \%$ of this was removed at night to supply a small amount of sensible heat flux and the negative net radiation. In contrast less than $25 \%$ of the energy stored during the day in the swash and surf zones was removed at night giving these zones a large net storage. The horizontal transport of energy into or out of the region, below the sea surface, provides an important bank for stored energy. The surface can make deposits to the oceanic reservoir during the summer or daylight hours and then withdraw what is needed in the winter or at night. This produces a more moderate climate than is found on land surfaces deprived of this readily available storehouse of energy.

The wet sand can be considered the true transition zone on the beach. The surf and swash zones are similar in their climatic 
Table 2. Daily energy budget (ly)

\begin{tabular}{|c|c|c|c|c|c|c|c|c|}
\hline & Source & & Loss & & Total & & & \\
\hline \multicolumn{9}{|l|}{ Dry zone } \\
\hline \multirow[t]{4}{*}{$\begin{array}{l}\text { Shortwave } \\
\text { Longwave }\end{array}$} & $\begin{array}{l}Q+q \\
I_{i} \text { day } \\
\text { Night }\end{array}$ & $\begin{array}{l}641 \\
396 \\
275\end{array}$ & $\begin{array}{l}A \\
I_{o} \text { day } \\
\text { Night }\end{array}$ & $\begin{array}{l}-\mathbf{1 7 0} \\
-\mathbf{5 7 0} \\
-\mathbf{3 3 0}\end{array}$ & $\begin{array}{l}Q+q-A \\
I \text { day } \\
\text { Night }\end{array}$ & $\begin{array}{r}471 \\
-174 \\
-\quad 55\end{array}$ & \multirow{3}{*}{$R$} & 471 \\
\hline & Total & 671 & Total & -900 & Total & -229 & & $\begin{array}{r}-229 \\
242\end{array}$ \\
\hline & $\begin{array}{l}-G \text { night } \\
-H \text { night }\end{array}$ & $\begin{array}{l}-21 \\
-\quad 33\end{array}$ & $\begin{array}{l}G \text { day } \\
H \text { day }\end{array}$ & $\begin{array}{r}-40 \\
260\end{array}$ & $\begin{array}{l}G \\
H \\
R\end{array}$ & $\begin{array}{r}19 \\
227 \\
246\end{array}$ & & \\
\hline & \multicolumn{8}{|c|}{ Wet sand zone } \\
\hline \multirow[t]{4}{*}{$\begin{array}{l}\text { Shortwave } \\
\text { Longwave }\end{array}$} & $\begin{array}{l}Q+q \\
I_{i} \text { day } \\
\text { Night }\end{array}$ & $\begin{array}{l}641 \\
396 \\
275\end{array}$ & $\begin{array}{l}A \\
I_{o} \text { day } \\
\text { Night }\end{array}$ & $\begin{array}{l}-120 \\
-497 \\
-339\end{array}$ & $\begin{array}{l}Q+q-A \\
I \text { day } \\
\text { Night }\end{array}$ & $\begin{array}{r}521 \\
101 \\
-\quad 64\end{array}$ & \multirow{3}{*}{$R$} & 521 \\
\hline & Total & 671 & Total & -836 & & -165 & & $\begin{array}{r}-165 \\
356\end{array}$ \\
\hline & $\begin{array}{l}-G \text { night } \\
-L E \text { night } \\
-H\end{array}$ & $\begin{array}{r}-\quad 38 \\
-\quad 33 \\
0\end{array}$ & $\begin{array}{l}Q \text { day } \\
L E \text { day } \\
H\end{array}$ & $\begin{array}{r}63 \\
230 \\
133\end{array}$ & $\begin{array}{l}G \\
L E \\
H \\
R\end{array}$ & $\begin{array}{r}25 \\
197 \\
133 \\
355\end{array}$ & & \\
\hline & \multicolumn{8}{|c|}{ Swash zone } \\
\hline \multirow[t]{4}{*}{$\begin{array}{l}\text { Shortwave } \\
\text { Longwave }\end{array}$} & $\begin{array}{l}Q+q \\
I_{i} \text { day } \\
\text { Night }\end{array}$ & $\begin{array}{l}641 \\
396 \\
275\end{array}$ & $\begin{array}{l}A \\
I_{0} \text { day } \\
\text { Night }\end{array}$ & $\begin{array}{l}-81 \\
-432 \\
-345\end{array}$ & $\begin{array}{l}Q+q-A \\
I \text { day } \\
\text { Night }\end{array}$ & $\begin{array}{r}560 \\
-\quad 36 \\
-\quad 70\end{array}$ & \multirow{4}{*}{$R$} & 560 \\
\hline & Total & 671 & Total & -777 & Total & -106 & & $\begin{array}{r}-106 \\
454\end{array}$ \\
\hline & $\begin{array}{l}-G \text { night } \\
-L E \\
-H\end{array}$ & $\begin{array}{r}-100 \\
0 \\
0\end{array}$ & $\begin{array}{l}Q \text { day } \\
L E \\
H\end{array}$ & $\begin{array}{r}406 \\
116 \\
32\end{array}$ & $\begin{array}{l}G \\
L E \\
H \\
R\end{array}$ & $\begin{array}{r}306 \\
116 \\
32 \\
454\end{array}$ & & \\
\hline & \multicolumn{7}{|c|}{ Surf zone } & \\
\hline \multirow[t]{4}{*}{$\begin{array}{l}\text { Shortwave } \\
\text { Longwave }\end{array}$} & $\begin{array}{l}Q+q \\
I_{1} \text { day } \\
\text { Night }\end{array}$ & $\begin{array}{l}641 \\
396 \\
275\end{array}$ & $\begin{array}{l}A \\
I_{\mathbf{0}} \text { day } \\
\text { Night }\end{array}$ & $\begin{array}{l}-\quad 45 \\
-423 \\
-347\end{array}$ & $\begin{array}{l}Q+q \\
I \text { day } \\
\text { Night }\end{array}$ & $\begin{array}{r}596 \\
-\quad 27 \\
-\quad 72\end{array}$ & \multirow{4}{*}{$R$} & 596 \\
\hline & Total & 671 & Total & -770 & Total & -99 & & $\begin{array}{r}99 \\
-\quad 497\end{array}$ \\
\hline & $\begin{array}{l}-G \text { night } \\
-L E \\
-H\end{array}$ & $\begin{array}{r}-112 \\
0 \\
0\end{array}$ & $\begin{array}{l}G \text { day } \\
L E \\
H\end{array}$ & $\begin{array}{r}487 \\
101 \\
23\end{array}$ & $\begin{array}{l}G \\
L E \\
H\end{array}$ & $\begin{array}{r}375 \\
101 \\
23\end{array}$ & & \\
\hline & & & & & $R$ & 499 & & \\
\hline
\end{tabular}

characteristics and represent the marine surface. Above the tide line, however, the soil moisture is in an intermediate state, as the amount of moisture decreases inland the climate becomes more extreme and continental. The wet sand is separated by a noticeable boundary from the saturated surface on one side and the completely dry sand on the other. It is the transition area between the completely wet and totally dry environments.

Table 2 presents the daily energy budget for the four beach zones. In some cases totals do not agree because of small deviations in rounding.
Studies that have attempted to map the distribution of net radiation on a global scale have shown marked discontinuities of the isolines along coasts (i.e. Budyko, 1963). This study has shown the abrupt variation in net radiation between the ocean and dry sand surfaces. Such a marked change in little over $100 \mathrm{~m}$ cannot be shown on a global scale map. The difference in net radiation between the surf and dry sand zones at noon on the clear day of May 9 was $0.57 \mathrm{ly} / \mathrm{min}$. If the primary effect of latitude is taken to be its determination of solar altitude and optical air mass (and, 
thus, solar radiation) this difference would represent a $35^{\circ}$ latitudinal displacement in a line of equal net radiation. The microclimate of the moist, wet sand surface is more representative of a mesic mid-latitude surface than is the dry sand. The latter would be a better analogy of dry desert regions. The noon difference in net radiation between the surf and wet sand zones would represent a $25^{\circ}$ isoline displacement. This demonstrates the great variations in surface microclimate that can occur over very small horizontal distances. The displacements would be less for cloudy conditions and average long term weather conditions. The noon dry sand-surf zone displacement with a day of high clouds (which may be taken to be more representative of long term weather conditions) was $12^{\circ}$.

\section{Air temperature and humidity}

Although this study deals primarily with radiation and energy balance parameters, brief mention should be made of air temperature and humidity for the sake of completeness. These parameters are, of course, the result of the energy transfers from the surface. Air temperature differences reached their maximum in the early afternoon. The dry sand was the warmest zone with a maximum temperature of $19.1^{\circ} \mathrm{C}$. The wet sand had a high of $18.2^{\circ}$ and the surf and swash zones $18.0^{\circ}$. The greatest difference occurred at 13:00 when the dry sand was $1.4^{\circ}$ warmer than the surf zone. The nocturnal temperatures showed the surf and swash zones the warmest with a low of $12.6^{\circ}$, the wet sand low was $12.2^{\circ}$, and the dry sand $12.0^{\circ}$. As with the energy balance parameters the day and night patterns were reversed and the absolute differential was less at night.
Vapor pressures were highest over the surf and swash zones with a noon value of 12.0 $\mathrm{mmHg}$. At the same time the wet sand had $11.5 \mathrm{mmHg}$ and the dry sand $11.3 \mathrm{mmHg}$.

The difference in afternoon air temperatures, coupled with the steady wind and thermal radiation were enough to create a noticeable difference in sensible temperature between the surf and dry sand.

\section{Conclusion}

This study has revealed the significant variations in local microclimate that can occur in a very small area. Surface moisture has a profound influence on local climate. An area such as a beach that shows rapid changes in surface characteristics will have correspondingly steep microclimatic gradients. On a slightly larger scale this leads to such well known phenomena as the land and sea breeze. Studies of this kind are needed to elaborate on the mechanisms of connection between a particular surface and its associated climate. It is only in this way that man will be able to modify the earth's surface in a purposeful way, being fully aware of the resulting climatic differences he is creating in the process. Because shorelines are the scene of a great deal of human habitation and reveal a wide range of climatic variation in a very small area they are a fruitful focus for such studies.

\section{Acknowledgements}

Thanks are due to Dr W. H. Terjung, University of California, Los Angeles, who supervised the work on which this paper is based and to Thomas Van Heuklon who assisted with the field work.

\section{REFERENCES}

Budyko, M. I. 1956. The heat balance of the earth's surface. Leningrad. Gidrometeorologicheskoe Izdatel'stvo. (Trans. by N. A. Stepanova, 1958, Washington, D.C., U.S. Dept. of Commerce). $259 \mathrm{pp}$.

Budyko, M. I. 1963. Atlas of the heat balance of the earth. Leningrad. Gidrometeorologischeskoe Izdatel'stvo.

Burt, W. 1954. Albedo over wind roughened water. J. Meteorol. 11, 283-290.

Dirmhirn, I. 1958. Untersuchungen an sternpyranometern. Archiv. Meteor., Geophys. Biokl., Ser. B. 9, 124-148.
Geiger, R. 1966. The climate near the ground. Harvard University Press, Cambridge. 611 pp.

Hofmann, G. 1966. Wärmehaushalt und advection. Archiv. Meteor. Geophys. Biokl., Ser. A.11, 474502.

Kazhdan, K., Kirillova, T. \& Preobrazhenskii, L. 1964. Results of observations on the radiation balance in the coastal region of the Black Sea. G.G.O., Trudy, Leningrad, 150, 125-132.

Kondratyev, K. 1969. Radiation in the atmosphere. Academic Press, New York. 912 pp.

Penman, H. L. 1956. Estimating evaporation. Trans. Am. Geophys. Un. 37, 43-50. 
Poltaraus, B. 1962. Radiatsionnyi rezhim u raione evapatorii pri nekotorykh tipakh letnei pogodyi vliianie na nego morei. Vestn. Mosk. Univ., Ser. 5, Geog., 1, 27-36.

Roden, G. 1959. On the heat and salt balance of the California Current region, J. Marine Res. 18, 36-61.

Sakali, K. \& Zorina, G. 1961. Comparison of the characteristics of the radiation balance of the land and sea surfaces on coastal strips. In Aktionmetriia: atmosferaia optika (ed. K. S. Shifrin) pp. 82-89. Gidrometeorizdat, Leningrad.

Sellers, W., 1965. Physical climatology. Univ. Chicago Press, Chicago. 272 pp.

Ter-Markariants, N., 1957. Radiation reflection from the sea during wave activity, $G . Q . O$. Trudy, Leningrad, 68, 166-171.

\section{МИКРОКЛИМАТИЧЕСКИЕ ВАРИАЦИИ БАЛАНСА ЭНЕРГИИ НА ПРИБРЕЖНОМ ПЛЯЖЕ}

Исследуются вариации әнергетического баланса микроклимата, которые происходят поперек прибрежного пляжа в ясный день. Для сравнения были выбраны 4 зоны пляжа, различающиеся только условиями влажности. Совершенно сухой песок с его высоким альбедо и горячей температурой поверхности в течение дня имеет наименьшее значение ревультирующего потока радиации. Более 90\% әтого потока переносилось в воздух путем теплопроводности. Поверхность влажного песка и водная поверхность в зоне прибоя имели более морской климат. Основ. ная часть результирующего потока радиации за сутки аккумулировалась в почве, в то время как главная часть остального потока шла на испарение. Зона мокрого песка пред- ставляла собой настоящую переходную область на пляже и обладала микроклиматом, промежуточным между случаями сухого песка и океана. Большая часть результирующего потока радиации шла на испарение, которое было большим, чем в полностью влажных зонах вследствие более высоких градиентов давления водяного пара. Видно, что существует заметное различие в микроклимате при условиях ясного неба на очень малых горизонтальных расстояниях, вызываемая различными условиями увлажнения поверхности. Картины днем и ночью обратны с разницей между зонами гораздо более резкими, что обусловлено влиянием притока солнечной радиации в течение дня. 